Fig. 2.-Slice of a Portland flint, from the Vale of Wardour, occurring vertically in the chalky series-Portion B-To show the pseudo. morphs after calcite or dolomite, and the radial crystallization of silica. By transmitted light; magnified $1 \times 55$.

" 3.-Part of the same slice-Portion A-To show section of a sponge spicule. By transmitted light; magnified $1 \times 120$.

"4.-Another part of the same slice-Portion A-To show the general character; sponge spicale, fragments of shell, \&c. A vein of chalcedony towards the right. By transmitted light; magnified $1 \times 25$.

"5.-Another part of the same slice-Portion A-To show the inlet of quartz, lined with agate-like bands of chalcedony, which here penetrates the general mass. By reflected light; magnified $1 \times 18$.

6.-The same. By transmitted light.

\title{
EXCURSION TO THE EAST END OF THE ISLE OF WIGHT.
}

Whit-Monday, June 6th, and two following days.

Director's :-Prof. J. Morris, M.A., F.G.S., F. G. H. Prict, Esq., F.G.S., and E. B. Tawney, Esq., M.A.

(Report by E. B. Tawney.)

The party arrived at Portsmouth by the mid-day train, and forthwith took passage in the steamer for Ryde. From hence a short railway journey brought them to Brading Station.

The first item in the programme was to visit the excavations at the Roman Villa. Accordingly the party, guided by Mr. Price, proceeded on foot to the Villa. A printed account of the discoveries was given to each member, while Mr. Price conducted the party round the works, explaining the plan of the original building, pointing out the mosaics in the different rooms, the hypocaust, \&c., and finally the well, which had just been re-excavated.

Returning to Brading Station, the members found awaiting them the little train which had been sent for them by R. B. Grantham, Esq., M.Inst.C.E., and H. S. Freeman, Esq., the Consulting and Resident Engineers of the Bembridge reclamation works.

A few minutes brought the party to New Harbour Works, where they were met by the above-named gentlemen, who indicated the points of interest in the scheme by which a great tract of 
land is being drained and reclaimed. The new sluices, which were near completion, were examined.

The party then walked along the bank which has been built to form the sea-wall to Bembridge Hotel, which was to be headquarters; and the luggage was sent across by boat through the kindness of the manager of the works.

Whit-Tuesday.-Mr. Freeman having kindly put his steam yacht at the disposal of those who preferred a sea voyage to a walk on foot to White Cliff Bay, some half-dozen members arailed themselves of his kind offer. White Cliff Bay was not, however, a favourable place for landing, and they had to disemabark with bare feet, and wade a short distance, arriving after the foot passengers.

The party then observed the coast section. Beginning at the east end of the Bay is seen the Chalk forming the headland of Culver Cliff, and rather inaccessible on this side. Lying against it, with the beds at first nearly vertical, are the red clays of the Woolwich Series, without fossils. Next, the London Clay, about 300 feet, was examined; at the base is an interesting conglomeratic basement-bed, containing pounded pebbles; and next the mottled red clay, \&c., a few feet above which is seen a greenishbrown sand, in which Ditrupa plana is abundant. Succeeding the London Clay is the Lower Bagshot Series, in which a mass of fragments of leaves is seen at one spot, but nothing entire was obtained. The Bracklesham beds are fairly fossiliferous in places, as described by the Rev. O. Fisher; but there was not time for the collection of these fossils, which, when obtained, are so difficult to preserve. In the Barton Clays nothing was found; nor could the party collect anything from the yellow sands of the Upper Bagshot, though officers of the Geological Survey here found casts of Cardium and other marine shells. Above the Upper Bagshot Sands were seen the fresh-water clays of the Lower Headon, in which ordinary fresh-water univalves are abundant; over these are occasional lignite beds a few inches thick.

Lying on the eroded surface of the green fresh-wrater clays are marine beds of the Middle Headon; the lowest two feet have been known since Mr. Fisher's paper (1862) to contain the Brockenhurst fauna, i.e., the same fossils that occurred in such abundance in the railway cutting in the New Forest in a bed only one foot thick. 


\section{Sections Mlustrating the Geology of the East end of the I. of Wight,}

By W. TOPLEY, Ese., F.G.S., Geological Survey of England.

SEction of WhItecliff baY (After Prof. J. Prestwich) SHOWING VARIOUS Classifications of THE Beds.

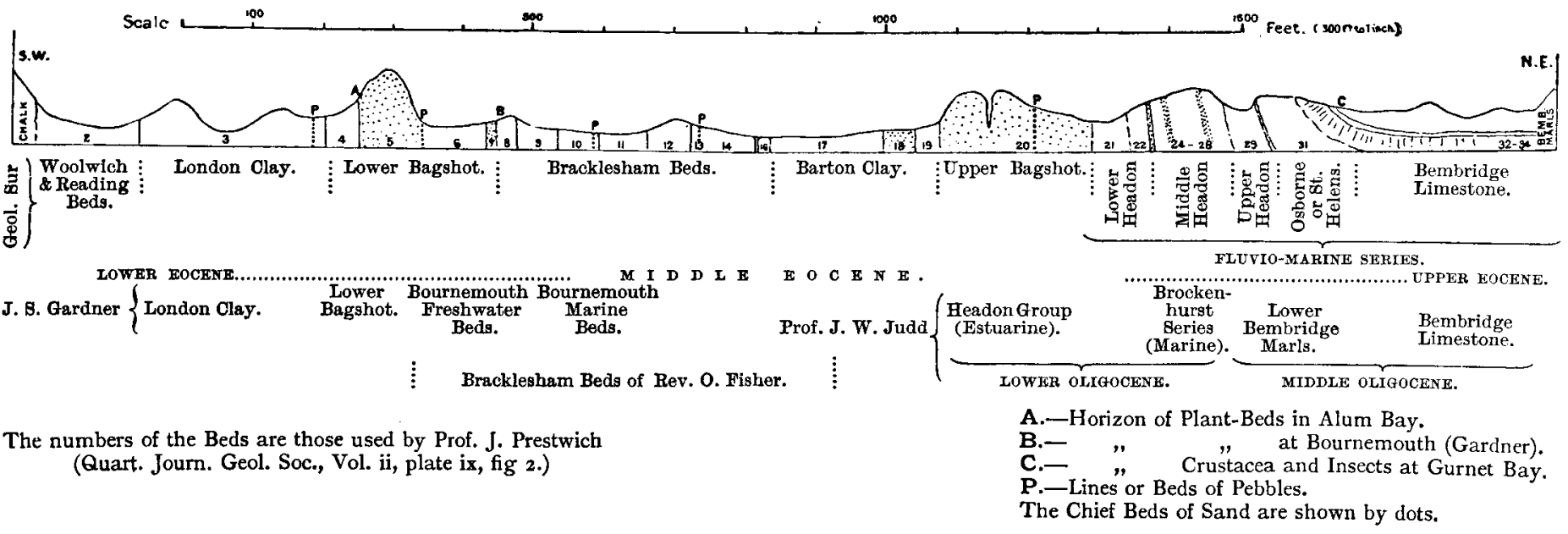

SECTION FROM SANDOWN BAY TO WHITECLIFF BAY.

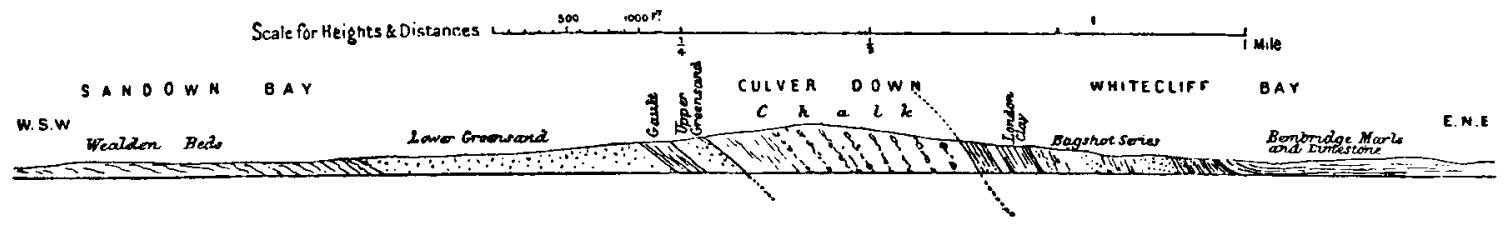


Above this bed fossils became scarcer for a few feet, but some 14 feet higher up is a rich band in the Middle Headon containing abundant $C y$ therea incrasata, Cerithium pseudocinctum, and other fossils characteristic of the same beds at Headon Hill, many of which were obtained by the members. After the Middle Headon there is a change again to fresh-water conditions in the Upper Headon, and the thin limestones near the top, crowded with fossils, attracted attention. These are succeeded by the mottled red and greenish clays of the Osborne series, which are apt to be grassed over in the cliff, but can be seen on the shore.

More attention was paid to the Bembridge Limestone, of which massive blocks strew the foreshore; it is a cream-coloured and often concretionary limestone, and contains Lymnea, \&c. Just at this period of the afternoon the rain began to descend, and advantage was taken of a rock-shelter formed by an overhanging ledge of Bembridge Limestone.

The walk over the rest of the series round by the Foreland was in rain, and very cold rain for that time of the year. The most fossiliferous places on the foreshore for the Bembridge Marls were still covered by the tide. However, the thin marine Ostrea Vectensis band near the base, about five feet above the Bembridge Limestone was well seen in the cliff; but after that nothing was picked up. The Gravel of the Foreland was passed in rain, but its continuation had been examined nearer Bembridge.

After dinner a vote of thanks to Messrs. Grantham and Freeman was passed for the kind arrangements which they had made for the reception of the party.

Wedresday.-In the morning the party walked to Sandown Bay by the Granite Fort to examine the Weald, the Neocomian and succeeding beds up to the Chalk.

At the top of the Weald the Perna-bed was found, i.e., loose blocks of it were seen lying about, owing to the tumbled state of the Wealden cliffs. The Weald first exposes mottled red beds, which occupy the shore for some distance; then the grey shales succeed, and these are rich in Cypridea Valdensis towards the top, while interstratified with them are limestones showing a brackish water condition, containing a dwarfed oyster, a small Modiola, Cyrena media, \&c., as on the Atherfield coast.

Except in the Perna-bed, no fossils were found in the Neocomian, though a great thickness is exposed under Redhill Battery, consisting of grey sandy clays, yellow and brown sand rock, \&c. 
Above the Neocomian follows the dark grey Gault clay; but neither the upper nor lower junctions of this clay are well seen now, and no fossils were found. The Upper Greensand seems to pass insensibly into the Gault, and the micaceous marls and sandstones at the base are poor in fossils. The glauconitic sandstone above has the true Upper Greensand characters, and the fossils are more abundant. The Chloritic Marl here can scarcely be made into a separate division, phosphatic nodules and fossils being the same as in the Greensand.

There was no time for working further round the point. Indeed the Chalk could only be examined at low water, or in fallen blocks.

A return was made up the zigzag path which leads past Redhill Battery, and so by Yaverland Manor House back to Brading.

The beauty of the scenery on a lovely morning compensated for the wet walk of the previous afternoon. The party returned to London by an afternoon train.

\section{EXCURSION TO HIGHAM, KENT.}

JUNE 18TH, 1881.

\section{(Report by the Director, W. WHITAKER.)}

The object of this excursion was to examine some cuttings on the railway through the Hundred of Hoo, which have laid open good sections of the Lower Tertiary beds. The excursion was probably the first in which the sections to be seen were as new to the Director as to those who trusted to his direction.

We were met at Higham Station by some gentlemen of the neighbourhood, amongst whom was the Rev. C. H. Fielding, of Higham, who kindly placed his knowledge of the country at our service. Our progress was also much aided by Mr. H. Russel, of Cliffe, by whose good offices we were carried along the line by a contractor's engine and truck, and so enabled to see all that the sanguine author of the programme (who was not present) had proposed, which could not otherwise have been done.

It may be better to describe the cuttings from west to east, without regard to the order in which they were actually seen, merely remarking that the district is part of the slight trough between the Thames and the Meàway, and is bounded on the south by a wooded range of London Clay hills, and on the 